\title{
Dynamics of Coffee Certifications in Producer Countries: Re-Examining the Tanzanian Status, Challenges and Impacts on Livelihoods and Environmental Conservation
}

\author{
Joseph Rajabu Kangile ${ }^{1,2, *}{ }^{\mathbb{C}}$, Reuben M. J. Kadigi ${ }^{1}$, Charles Peter Mgeni $^{1}{ }^{1}$, Bernadetha Pantaleo Munishi ${ }^{3}$, \\ Japhet Kashaigili ${ }^{4}$ and Pantaleo K. T. Munishi ${ }^{4}$
}

1 School of Agricultural Economics and Business Studies, Sokoine University of Agriculture (SUA), Morogoro P.O. Box 3007, Tanzania; rmjkadigi@sua.ac.tz (R.M.J.K.); chrlsmgeni099@sua.ac.tz (C.P.M.)

2 Socio-Economics and Marketing Research Section, TARI Dakawa Centre, Tanzania Agricultural Research Institute (TARI), Morogoro P.O. Box 1892, Tanzania

3 Directorate of Research and Innovations, Tanzania Agricultural Research Institute (TARI), Dodoma P.O. Box 1571, Tanzania; bernadetha.munishi@tari.go.tz

4 College of Forestry, Wildlife and Tourism, Sokoine University of Agriculture (SUA), Morogoro P.O. Box 3007, Tanzania; jkashaigili@sua.ac.tz (J.K.); munishi@sua.ac.tz (P.K.T.M.)

* Correspondence: kangilej@gmail.com; Tel.: +255-755-248598

check for updates

Citation: Kangile, J.R.; Kadigi, R.M.J.; Mgeni, C.P.; Munishi, B.P.; Kashaigili, J.; Munishi, P.K.T. Dynamics of Coffee Certifications in Producer Countries: Re-Examining the Tanzanian Status, Challenges and Impacts on Livelihoods and Environmental Conservation. Agriculture 2021, 11, 931. https://doi.org/10.3390/ agriculture11100931

\section{Academic Editors:}

Selma Boumerdassi, Eric Renault and Christopher Robin Bryant

Received: 8 September 2021

Accepted: 20 September 2021

Published: 27 September 2021

Publisher's Note: MDPI stays neutral with regard to jurisdictional claims in published maps and institutional affiliations.

Copyright: (c) 2021 by the authors. Licensee MDPI, Basel, Switzerland. This article is an open access article distributed under the terms and conditions of the Creative Commons Attribution (CC BY) license (https:// creativecommons.org/licenses/by/ $4.0 /)$.

\begin{abstract}
Certification is increasingly becoming necessary for accessing coffee export markets and practicing environmental conservation, especially at this time when many of the farmers in developing countries strive to achieve agricultural transformation. Using data from 400 randomly selected coffee farmers in Tanzania, the study determined the status, constraints, key drivers, and impact of coffee certifications. Descriptive statistics and the endogenous switching regression (ESR) model were used for data analysis. Results indicated that the level of coffee certification is low, being constrained by unawareness and inaccessibility, the prevalence of coffee diseases, failure in realizing price advantages, and certification not being cost effective. Economies of scale, experience, and participation in collective actions are significant factors affecting coffee farmers' decision to join certification schemes. Additionally, the study rejects the hypothesis of certification to improve household income. However, certification improved awareness and practices of environmental conservation among coffee farmers. It is thus important to embark on awareness creation and make certification services accessible and cost effective to coffee farmers for increased access to niche export markets. Easing transmission of price premiums to coffee farmers will also increase the supply of sustainably grown coffee, improve coffee farmers' livelihood, and help in the attainment of environmental sustainability goals within the coffee supply chain.
\end{abstract}

Keywords: sustainability; endogenous switching regression; coffee; certification; environmental conservation; livelihoods

\section{Introduction}

Certification is an important economic tool that is used to promote social-economic and environmental conservation objectives in the world [1]. It is used to stimulate quality and sustainability standards where consumers pay price premiums to promote social and economic change and environmental sustainability in the world $[2,3]$. Through these arrangements, farmers adhere to set standards so that they can benefit from price premiums and other related advantages associated with certification. However, certification is voluntary and it is used as a tool to access markets while attaining sustainability goals within the commodity supply chains. Farmers are thus required to comply with the set sustainability measures and regulations in order to enable them to access the benefits of certification [4]. 
Certification involves a number of stakeholders, hence there are various certification schemes covering a range of issues within the sustainability framework. For example, retailers introduce quality standards responding to the consumers' requirements; nongovernmental organizations focus on achieving suitability goals; and governments in exporting countries aim at promoting a sustainable crop commodity industry. Other certification schemes are developed by specific product industries, such as the coffee industry with an interest in promoting coffee products [3]. This is done to achieve sustainable development. According to the Food and Agriculture Organization of the United Nations FAO [5], sustainable development is "the management and conservation of the natural resource base, and the orientation of technological and institutional change in such a manner as to ensure the attainment and continued satisfaction of human needs for present and future generations. Such sustainable development (in the agriculture sector in particular) conserves land, water, plant and animal genetic resources, in environmentally non-degrading, technologically appropriate, economically viable and socially acceptable way". Therefore, retailers, non-governmental organizations, governments, and other actors of the private sector have developed certification schemes aimed at achieving sustainable development.

For coffee, the most widely used certification standards are Fairtrade (according to Fair Trade Labelling Organization International), organic (according to the International Federation of Organic Agriculture Movements), 4C (Common Code for the Coffee Community), and Rainforest Alliance, which was merged with UTZ, certified in January 2018 [3,6,7]. Some private companies, such as Coffee and Farmer Equity (C.A.F.E) Practices by Starbucks and Nespresso AAA, provide their own coffee certifications. There are also many others, such as Smithsonian Migratory Bird Center (SMBC) Bird Friendly Certification, and Demeter, just to mention a few. These certification schemes provide independent, credible, traceable, and innovative solutions for sustainable supply chains of coffee [3,8]. They ensure that farmers produce certified coffee for specific intended markets. Certified coffee is intended to be grown in a healthy environment, it is economically viable to farmers, and promotes social equity among farmers and other workers within the coffee supply chain [8].

Coffee certification schemes work along three main sustainability dimensions of social, economic, and environmental conservation. Social and economic benefits include access to markets, price premiums, better trading conditions, and stabilization in coffee prices $[7,8]$. Environmental conservation is enhanced through practices such as reduced use of agrochemicals, water conservation, soil erosion, energy use, and biodiversity conservation $[7,9]$. Additionally, the benefits of certification can extend to increased yields and better management of farmer associations [1]. This is because some certification schemes such as Fairtrade, which is granted to cooperatives and associations and not to individual farmers, are accompanied by improved management of collective action groups.

Certification has made progress in the world and continues to show its importance due to the increasing demand for certified coffee by buyers in consuming countries. The demand for sourcing healthier and sustainably grown coffee has grown in recent years [10]. Therefore, many coffee-producing countries in the world are supplying sustainably grown coffee to consumers. Tanzania is one of the developing countries supplying non-sustainable and sustainably grown coffee, including organic, rainforest-certified, and fair-traded coffee.

Coffee production in Tanzania started in 1898. The crop was first introduced in Kilimanjaro region, Northern zone of Tanzania by Catholic missionaries, and the crop is now grown in three zones of the country [11]. These are the Northern zone made up of Kilimanjaro, Arusha, and Manyara regions; the Western zone made up of Kagera, Mara, and Kigoma regions; and the Southern highlands zone made up of Mbeya, Songwe, and Ruvuma regions. There are also emerging regions which have started to grow coffee in the Southern highlands (i.e., Iringa and Rukwa regions). Other coffee-producing regions are shown in Figure 1. 


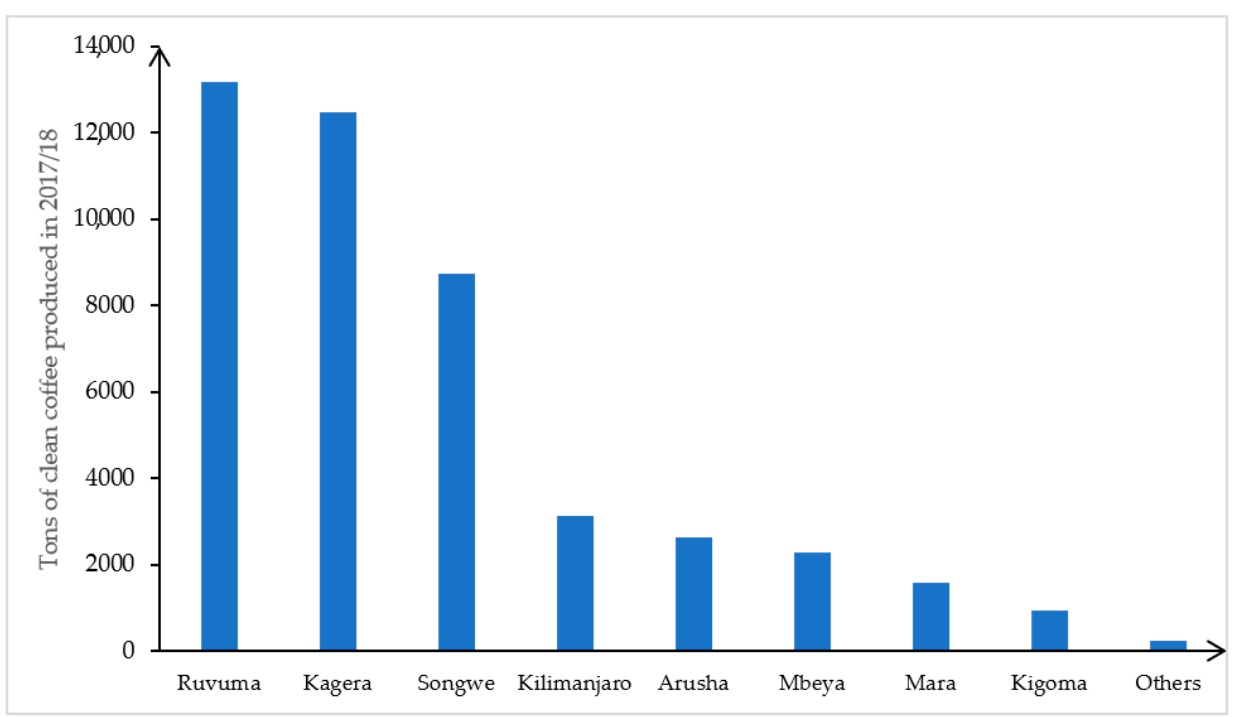

Figure 1. Coffee-producing regions in Tanzania. Source: computed from Ministry of Agriculture (MoA), 2018 data.

There are two types of coffee grown in Tanzania, namely, Robusta (Coffea canephora L. (Gentianales: Rubiaceae)) and Arabica (Coffea arabica L.). Arabica coffee makes up about $70 \%$ of the total coffee produced in Tanzania. The Arabica coffee produced in Tanzania is of Colombian origin, "Colombian Mild Arabica", which is used as a filler with other coffee types. Robusta coffee makes up 30\% of the total coffee produced in the country [12] The level of coffee production in the country has increased from 33,000 tons in 1961 to 51,529 tons of green coffee ( 859 thousand $60 \mathrm{~kg}$ bags) in 2019 (FAO, 2020) (Figure 2). The coffee production trajectory reached its increasing trend in the year 2000 to 2005, attaining a production level of 95,390 tons of green coffee, which was the highest in Tanzania coffee production history.

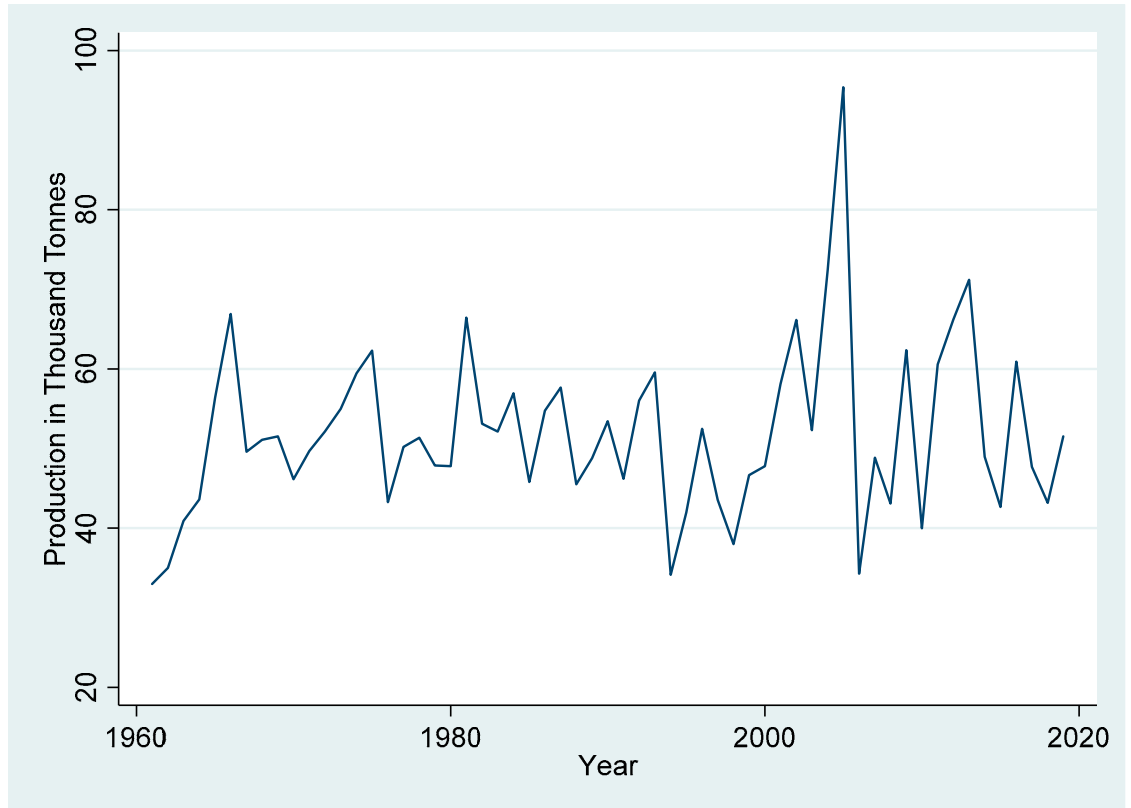

Figure 2. Coffee production in Tanzania. Source: computed from FAOSTAT 2020 data.

Tanzania has continued producing coffee and it is now among the top five coffeeproducing countries in Africa. Africa makes up about $11 \%$ of the total global coffee production with Ethiopia, Uganda, Côte d'Ivoire, Madagascar, and Tanzania being the 
top five coffee producers [13]. These five countries produce about $76 \%$ of the total coffee produced in Africa [14]. Tanzania contributes about $1.7 \%$ to the total share of coffee production in the world [15]. Coffee production in Tanzania is dominated by small-scale farmers $(90 \%)$.

Tanzania experiences a positive static export trend for coffee. The country exports about $93 \%$ of the total coffee produced [12]. For example, Tanzania exported coffee worth USD 165 million in the year 2019 [16]. Available statistics indicate that about $70 \%$ of the Tanzania coffee is exported to six markets, which are Germany, Italy, the United States of America, Japan, Belgium, and the United Kingdom [16]. The coffee trade is increasing due to favorable Arabica coffee prices and the accessibility of the country to niche export coffee markets. These niche export markets are Fairtrade, Rainforest Alliance, and organic coffee markets [7]. For example, the Arabica price increased by $10.3 \%$ for the coffee exported by Tanzania in the year 2020 [17].

Tanzania, as with many other coffee-producing countries in the world, accesses niche export coffee markets by complying with quality and standards set in these markets. Standards set in these markets include sustainability standards. The main certification schemes operating in Tanzania are Organic, Fairtrade, and Rainforest Alliance. There are also specific companies' certifications in Tanzania such as C.A.F.E Practices by Starbucks. All these certification schemes ensure that coffee sourced from Tanzania is healthier and sustainably grown.

Despite an increasing demand for sustainably sourced coffee, the level of certified coffee production has been declining in the world. Available statistics show that in the period of 2014 to 2018 the production of certified coffee dropped by 15.1\% [18]. In the same period, the area under certified coffee production also dropped by $12.2 \%$. Certified coffee represented a $25.8 \%$ share of the global total coffee production by the year 2018 [3]. Likewise, in Tanzania, as one of the coffee-producing countries, the trend is the same.

Certification schemes are charged with being ineffective, especially in sustainability awareness, transparency, and monitoring of social, environmental, and economic impacts [19]. In many coffee-producing countries, the overall impact of certification schemes on the coffee farmers has been hard to establish [1,20-22]. Therefore, understanding the key constraints to certification, drivers, and impact of certification on the coffee sector in producer countries is important for crafting policies that will spur the production of sustainably grown coffee, social equity, and overall sustainability within the coffee supply chain. This study established the status, constraints, key drivers, and the impact of coffee certification in Tanzania.

\section{Materials and Methods}

\subsection{Description of the Study Area}

The study was conducted in three main coffee-producing zones of Tanzania. The Southern highlands comprised Ruvuma and Songwe regions. In the Northern zone, the study was carried out in Kilimanjaro region. The Western zone was represented by Kagera region. The study was carried out in districts with a high level of coffee production. These districts were Muleba and Karagwe in Kagera region; Mbinga and Songea in Ruvuma region; Mbozi and Ileje in Songwe region; and Moshi and Hai in Kilimanjaro region. The four regions surveyed are among the 13 regions involved in coffee production in Tanzania. These four regions represent $83 \%$ of the total coffee production in the country. Ruvuma and Kagera regions are the leading regions in coffee production. Ruvuma alone represents about $30 \%$ of the total coffee produced in the country [23]. The distribution of coffee farmers involved in the study is shown in Figure 3. 


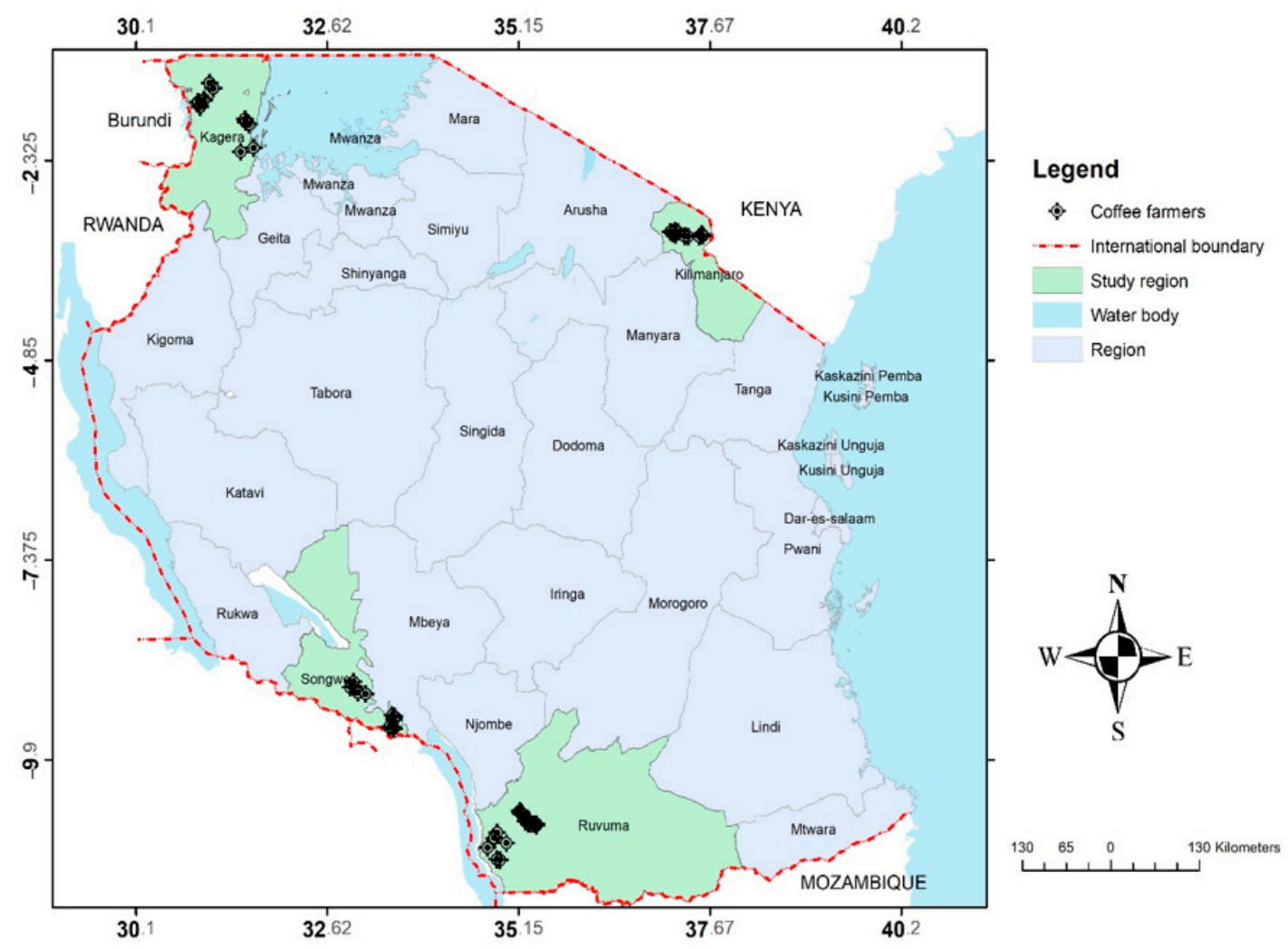

Figure 3. Map showing regions in Tanzania and the distribution of coffee farmers involved in the study. Source: sketched using coffee farmers' household survey global positioning system (GPS) 2021 data.

\subsection{Conceptual and Theoretical Framework}

This study synergizes two theories in explaining what influences coffee farmers to become certified. These theories are the random utility theory and the profit maximization theory. The random utility theory is based on the random utility framework (RUF) and its assumptions as stated by Nicholson and Snyder [24] and Cascetta [25]. The theory hypothesizes that every farmer is a rational decision maker, maximizing utility relative to his or her choice of participating in voluntary certification schemes or not. In tandem, according to the profit maximization theory, the farmer is attracted by monetary returns in making the decision. In theory, farmers always act in self-interest to maximize profits [26,27].

Farmers are the maximizers of the utility of the potential monetary payoffs [28]. In maximizing profits, farmers are assumed to equate marginal revenues to marginal cost of producing the commodity. The decision of the coffee farmer $i$ whether to become certified or not is based on the following rationality assumptions;

(i) The coffee farmer $i$ considers the choice between becoming certified or not as being mutually exclusive alternatives.

(ii) The coffee farmer $i$ assigns to each alternative a perceived utility and selects the alternative that maximizes utility.

(iii) The utility assigned to each choice alternative $j$ depends on a number of attributes of the alternative itself and of the coffee farmer $i$.

$$
U_{j}^{i}=U^{i}\left(x_{j}^{i}\right)
$$

where $x_{j}$ is the vector of attributes relative to the alternative $j$ and to the decisionmaker $i$.

(iv) The utility assigned by the coffee farmer is not known with certainty and thus is represented by a random variable. 
Conceptually, the decision of the coffee farmer to select whether to join a certification scheme or not is influenced by many factors which are conditioned on the farmer $i$ (Figure 4). These determinants of certification include education level, economies of scale in coffee production, membership in organizations, the market outlet used in selling coffee, sex, experience in coffee production activities, and wealth or poverty level. In the choice of becoming certified, the coffee farmer maximizes utility. However, based on the random utility assumptions, the utility assigned depends on the attributes of the alternative chosen. The attributes associated with certifications are the socioeconomic and environmental benefits. It follows therefore that coffee farmers are attracted by monetary payoffs which are in terms of socioeconomic and environmental benefits. The socioeconomic benefits include increased coffee farmers' income, enhanced market access, price premiums, better trading conditions, and stabilization in coffee prices. The practices associated with complying with certification may contribute to the improved health status of the coffee farmers. Environmental conservation is enhanced through benefits such as reduced use of inorganic fertilizers and agrochemicals, water conservation, enhanced soil health, biodiversity conservation, protection of natural ecosystems, and resilience as the result of adaptations to climate change.

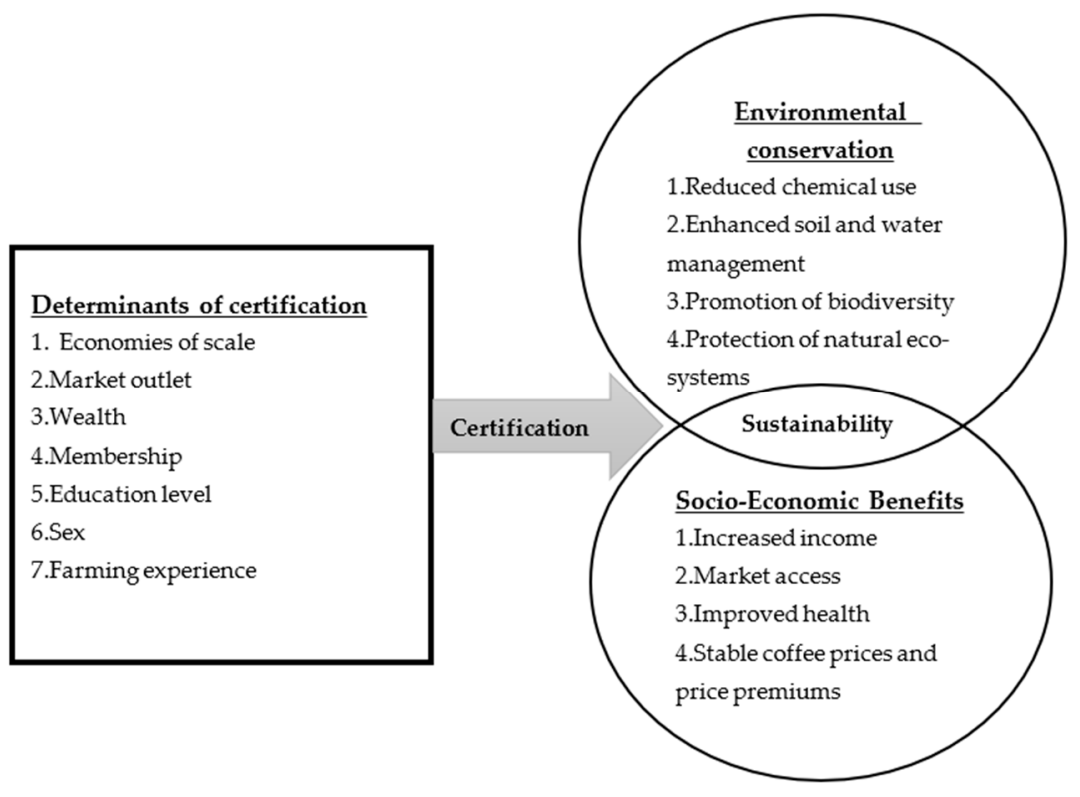

Figure 4. Conceptual framework. Source: adapted from Rosen and Kishawy [9] and Pyk and Hatab [7].

\subsection{Data, Sampling Procedures, and Sample Size}

Data for the study were collected by field survey method in January 2021 from 400 coffee farmers in four selected regions of Tanzania. The data collection activity was preceded by requesting the approval on Code of Practice on Ethical Standards in Research which includes the General Data Protection Regulations (GDPR). Data were collected using a semi-structured questionnaire implemented using Computer Aided Personal Interviews (CAPI).

The study used a multistage random sampling method comprising four stages. The first stage was purposive selection of four regions, taking into consideration their level of coffee production (based on production level, Ministry of Agriculture, 2018 data). The second stage of district selection was also based on the same criterion of high level of coffee production and it involved selection of two districts from each region. The third stage involved selection of five enumeration areas (EAs)/villages using probability proportional to size (PPS) from each of the selected districts in stage two. The fourth stage involved 
random selection of 10 farmers from each enumeration area, making a total of 50 farmers per district.

The sample size $(n)$ was estimated considering the target population $(\mathrm{N})$ and using a 95\% confidence interval level that is $d=5 \%$ based on Yamane [29] as shown in Equation (2) below. Available statistics indicate that these four regions have a total of 172,688 coffee farmers (N) [23]. This gives a sample size of 399.1, which is exactly 400 farmers that were interviewed.

$$
n=\frac{N}{1+N d^{2}}
$$

\subsection{Analytical Framework}

This study used a combination of approaches in its analytical framework. This included descriptive statistics analysis to depict the levels of the variables under study and the association among the variables. In showing the association among the variables of interest, the chi-square statistic was used. Tests of significance between the variables were implemented using $t$-tests.

Data reduction for Likert scales and creation of summated scales were conducted using the exploratory (factor analysis) model. Measure of sampling adequacy (MSA) and sphericity tests were performed prior to estimation of the factor analysis model to see whether the correlations are large enough to be suitable for factor analysis. The KaiserMeyer-Olkin (KMO) measure of sampling adequacy was found to be greater than 0.5 and the Bartlett's test of sphericity was significant $(p<0.05)$, implying that the correlations were large enough, hence it was necessary and sufficient to use the factor analysis model in data reduction.

Participation in voluntary certification schemes was modelled under RUF. This means that if a coffee farmer decides to enter into the certification scheme, it means that there is utility gain that the farmer expects to obtain from participating in the scheme. The expected benefits that can be gained include social, economic, and/or environmental conservation gains. RUF is assumed to guide coffee farmers on making choices between being certified and not being certified. Coffee farmers choose the alternative which maximizes utility such that; $U_{1^{1}}$ is the utility that coffee farmer $i$ gets if certification is chosen and $U_{0^{i}}$ is the utility that coffee farmer $i$ gets if they choose not to join the certification scheme. The endogenous switching regression (ESR) model was used in modelling the two scenarios in two stages. The first stage of the ESR model is the estimation of the decision to become certified which was estimated through the probit model. The second stage is the estimation of the effect of the decisions on two outcome variables, which are household income and benefits of environmental conservation. The choice of whether to become certified or not is influenced by various factors $\left(Z_{i}\right)$, thus the latent model in Equation (3) could be estimated.

$$
C_{i}^{*}=\underset{\sim i \sim k}{Z} \underset{i}{\alpha}+\varepsilon_{i}
$$

The problem with the above model is that $C_{i}^{*}$ is unobservable as the utility of a coffee farmer cannot be observed [24], but choices made by a coffee farmer give some information. Considering Equation (4), it follows that, if $C_{i}=1$ then $C_{i}^{*}>0$ and if $C_{i}=0$ then $C_{i}^{*} \leq 0$. This implies that, if a coffee farmer makes choice 1 , it must be the case that utility of alternative 1 is the highest.

$$
C_{i}^{*}=U_{i_{1}}-U_{i_{o}}
$$

The probability of a coffee farmer deciding whether to become certified or not was determined by combining the regression equation for the unobservable $C_{i}^{*}$ and the equation that links $C_{i}$ and $C_{i}^{*}$ as expressed in Equation (5).

$$
C_{i}^{*}=Z_{i k}^{\alpha}+\varepsilon_{i} ; C_{i}=\left\{\begin{array}{l}
1 \text { if } C_{i}^{*}>0 \\
0 \text { if } C_{i}^{*} \leq 0
\end{array}\right.
$$


where $\underset{\sim i}{Z}$ represents an array of factors hypothesized to influence the decision of whether to become certified or not (Table 1 ) and $\underset{\sim}{\alpha}$ represents the parameters to be estimated.

Table 1. Description of variables for the endogenous switching regression model.

\begin{tabular}{|c|c|c|}
\hline Level of the Variable & Variable & Description of the Variable \\
\hline \multirow{5}{*}{$\begin{array}{l}\text { Environmental } \\
\text { conservation and } \\
\text { household income level } \\
\text { impact variables }\end{array}$} & $x_{1}=\operatorname{Sex}$ & Sex of the coffee plot manager measured as 1 if male and 0 if female \\
\hline & $\mathrm{x}_{2}=$ Education & Years spent in formal training by the plot manager \\
\hline & $\mathrm{x}_{3}=$ Level of specialization & $\begin{array}{l}\text { The measure of economies of scale calculated as the ratio of the } \\
\text { coffee farm size to the total farm size of the entire household crop } \\
\text { enterprise. }\end{array}$ \\
\hline & $\mathrm{x}_{4}=$ Membership & $\begin{array}{l}\text { Membership in organizations as the measure of participation in } \\
\text { collective action presented as number of organizations where the } \\
\text { farmer has membership }\end{array}$ \\
\hline & $\mathrm{x}_{5}=$ Market outlet & $\begin{array}{c}\text { The type of market used by the farmer in selling coffee, coded as } 1 \\
\text { if sold through the designated Agricultural Marketing Cooperative } \\
\text { Societies (AMCOS) and } 0 \text { otherwise. }\end{array}$ \\
\hline \multirow{7}{*}{$\begin{array}{l}\text { Drivers of certification } \\
\text { decision }\end{array}$} & $\mathrm{Z}_{1}=$ Education & Years spent in formal training \\
\hline & $Z_{2}=$ Level of specialization & $\begin{array}{l}\text { The measure of economies of scale calculated as the ratio of the } \\
\text { coffee farm size to the total farm size of the entire household crop } \\
\text { enterprise }\end{array}$ \\
\hline & $\mathrm{Z}_{3}=$ Membership & $\begin{array}{l}\text { Membership in organizations as the measure of participation in } \\
\text { collective action presented as number of organizations where the } \\
\text { farmer has membership }\end{array}$ \\
\hline & $\mathrm{Z}_{4}=$ Market outlet & $\begin{array}{c}\text { The type of market used by the farmer in selling coffee, coded as } 1 \\
\text { if sold through the designated AMCOS and } 0 \text { if sold directly } \\
\text { through private buyers and other outlets. }\end{array}$ \\
\hline & $Z_{5}=\operatorname{Sex}$ & Sex of the coffee plot manager measured as 1 if male and 0 if female \\
\hline & $Z_{6}=$ Experience & Years of experience in coffee-farming activities \\
\hline & $\mathrm{Z}_{7}=$ Wealth & $\begin{array}{l}\text { Wealth of the coffee farmer measured as total value of household } \\
\text { owned assets in USD }+\end{array}$ \\
\hline
\end{tabular}

+1 USD = 2305.10 TZS, the average exchange rate for the year 2020 BOT, Bank of Tanzania Annual Report, 2020, Bank of Tanzania: Dar es Salaam, p. 247, data. X1-X5 are the factors hypothesized to affect the outcome variables that is environmental conservation and household incomes; Z1-Z7 are factors assumed to drive the decision of farmers to get certified; AMCOS is the Agricultural and Marketing Cooperative Societies

The effects of certification on household income and the gains from environmental conservation were estimated in two equations. The ESR model was run two times since the outcome variables of interest were two. The first run involved the outcome variable being livelihood improvement which was measured by total household income and the second run of the model involved using environmental conservation as the outcome variable. The total household income was calculated from the coffee income, livestock income, vegetable and fruits income, income from other crops, remittances, salaries/wages, businesses, and income from off-farm economic activities.

The environmental conservation outcome variable was calculated through the data reduction method using factor analysis. The summated scale method was used in creating the variable to measure environmental conservation from 5-point Likert scale statements. These statements were awareness of environmental effects; awareness of sustainable practices; practice of sustainable coffee production; existence of barriers to sustainable coffee production; and the measures used to minimize environmental effects.

The outcome equation for the two regimes, which involves certification status ( 1 if certified and 0 if not certified), was estimated in two equations that were combined in the ESR model $[1,22,30]$. The models in Equations (6) and (7) were combined and estimated in 
Stata software using the movestay command with the full information maximum likelihood method [31,32].

$$
\begin{gathered}
\text { Regime 1: } Y_{1 i}=\underset{\sim 1}{X_{1}^{\prime}}{ }_{i} \beta_{k}+\varepsilon_{1 i} \text { if } C_{1 i}=1 \text {; certified coffee farmers } \\
\text { Regime 2: } Y_{0 i}=\underset{\sim}{X_{0}^{\prime}}{ }_{i} \beta_{\sim}+\varepsilon_{0 i} \text { if } C_{0 i}=0 \text {; not certified coffee farmers }
\end{gathered}
$$

where $Y_{i}$ represents the outcome variables total household income and environmental conservation and $\underset{\sim}{X^{\prime}}$ are the factors assumed to affect the outcome variables (Table 1).

The post-estimation was implemented using the mspredict [32] command and the procedure was used in the estimation of the average treatment effects on the treated (ATT) and the average treatment effects on the untreated (ATU) to deduce the effects of the certification decisions on the outcome variables which are household income and environmental conservation. ATT was calculated as the difference between the expected value of the real scenario outcome from certification and its corresponding counterfactual outcome scenario. Similarly, ATU was calculated as the difference between the expected value of the real scenario outcome from non-certified coffee farmers and its corresponding counterfactual outcome scenario.

\section{Results}

\subsection{Socioeconomic Characteristics of Coffee Farmers}

Participation of coffee farmers in certification schemes is low. Findings indicate that $70.5 \%$ of the farmers involved in the study were not participating in any certification scheme. The remaining proportion of farmers $(29.5 \%)$ was in various certification schemes which are Organic, Rainforest Alliance, and Fairtrade certification schemes. Summary statistics of the sampled coffee farmers are provided in Table 2. It is clear that most farmers who were not engaged in certification schemes were male adults. They were not specialized in coffee production, and had a high level of literacy. The results indicate significant variations between the level of specialization, age of the coffee farmer, and certification $(p<0.05)$. The more specialized coffee farmers were engaged more in certification schemes than their counterpart coffee farmers with low levels of specialization. Additionally, old people ( $\leq 60$ years) participated more in the certification schemes than adults (36-59 years) and youth ( $\leq 35$ years). Generally, coffee production activities seemed to not be economically attractive to youth as only $11 \%$ of the farmers were youth. Land ownership might also be constraining youth from taking part in coffee production activities given the fact that the crop is perennial.

\begin{tabular}{|c|c|c|c|c|c|}
\hline \multirow{2}{*}{\multicolumn{2}{|c|}{ Socioeconomic Variable (\%) }} & \multicolumn{2}{|c|}{ Certification } & \multirow{4}{*}{$\begin{array}{c}\begin{array}{c}\text { Overall } \\
(n=400)\end{array} \\
87 \\
13\end{array}$} & \multirow{4}{*}{$\begin{array}{c}\chi^{2} \text { Statistics } \\
0.582(0.446) \dagger\end{array}$} \\
\hline & & \multirow{3}{*}{$\begin{array}{c}\text { Certified }(\boldsymbol{n}=\mathbf{1 1 8}) \\
88.98 \\
11.02\end{array}$} & \multirow{2}{*}{$\begin{array}{c}\text { Non-Certified }(n=\mathbf{2 8 2}) \\
86.17\end{array}$} & & \\
\hline & Male & & & & \\
\hline Sex & Female & & 13.83 & & \\
\hline & Youth ( $\leq 35$ years) & 4.24 & 13.83 & 11 & \\
\hline Age & Adult (36 to 59 years) & 56.78 & 57.45 & 57.25 & $9.723(0.008)^{* * *}$ \\
\hline \multirow{4}{*}{ Education level } & Old ( $\geq 60$ years $)$ & 38.98 & 28.72 & 31.75 & \\
\hline & No formal education & 0.85 & 0.71 & 0.75 & \\
\hline & Primary education & 82.2 & 82.98 & 82.75 & $0.048(0.976)$ \\
\hline & $\begin{array}{l}\text { Secondary education } \\
\text { and above }\end{array}$ & 16.95 & 16.3 & 16.50 & \\
\hline \multirow{3}{*}{$\begin{array}{c}\text { Level of } \\
\text { specialization }\end{array}$} & Less than $25 \%$ & 11.86 & 27.3 & 22.75 & \\
\hline & $25-50 \%$ & 45.76 & 51.06 & 49.50 & $22.12(0.00)^{* * *}$ \\
\hline & More than $50 \%$ & 42.38 & 21.7 & 27.75 & \\
\hline
\end{tabular}

Table 2. Socioeconomic characteristics of coffee farmers involved in the study. 


\subsection{Coffee Farmers' Participation in Collective Action}

The participation of coffee farmers in collective actions facilitated access and decision to participate in certification schemes. Our results of analysis show that $91.3 \%$ of all the farmers have membership in various organizations. Many farmers who have membership in various organizations (98.1\%) had membership in agricultural/livestock/fisheries farmer groups, including marketing groups such as agricultural and marketing cooperative societies. The other organizations with a high proportion of coffee farmers were trade and business associations and credit or microfinance groups, including saving and credit cooperative societies (SACCOS) and village saving and lending associations (VSLAs), with $13.7 \%$ and $12.6 \%$ of coffee farmers, respectively.

Additionally, participation in collective action facilitated collective sales of coffee and other agricultural produce. Results show that $89.5 \%$ of the coffee farmers used AMCOS as the key market outlet for their coffee. This shows that more coffee farmers who were members in various organizations and used AMCOS as their market outlets were in certification schemes (Table 3). Coffee farmers who did not use AMCOS as their market outlet sold their coffee through middlemen, local villagers/neighbors, cottage processors, and other processing companies. In fact, many studies have reported the importance of agricultural farmers participating in collective action activities. Participation in collective action will not only make farmers benefit from collective sales but there are other advantages, including environmental conservation methods that can be obtained through participation in collective action. The studies by Barham and Chitemi [33], Ochieng, Knerr [34], and Twine, Rao [35] have showed that sharing of technical knowledge and access to credit constituted several benefits that can be obtained through farmers' participation in collective action.

Table 3. Participation in collective action and points of sale among coffee farmers.

\begin{tabular}{|c|c|c|c|c|c|}
\hline \multirow{2}{*}{\multicolumn{2}{|c|}{ Variable (\%) }} & \multicolumn{2}{|c|}{ Certification } & \multirow{4}{*}{$\begin{array}{c}\text { Overall }(n=400) \\
91.25 \\
8.75\end{array}$} & \multirow{3}{*}{$\begin{array}{c}\chi^{2} \text { Statistics } \\
13.09(0.00)+^{* * *}\end{array}$} \\
\hline & & \multirow{2}{*}{$\begin{array}{c}\text { Certified }(n=\mathbf{1 1 8}) \\
99.15\end{array}$} & \multirow{2}{*}{$\begin{array}{c}\text { Non-Certified }(n=282) \\
87.94\end{array}$} & & \\
\hline Membership in & Members & & & & \\
\hline organizations & Non-members & 0.85 & 12.06 & & $13.09(0.00)+x+x$ \\
\hline \multirow{2}{*}{ Market outlet } & AMCOS & 95.76 & 86.88 & 89.5 & \multirow{2}{*}{$6.96(0.008)^{* * *}$} \\
\hline & Others $\ddagger$ & 4.24 & 13.12 & 10.5 & \\
\hline
\end{tabular}

$\ddagger$ Others include middlemen, cottage processors, and local villagers/neighbors. + Values in brackets are $p$-values; ${ }^{* * *} p<0.01 ; n$ is number of farmers/observations

\subsection{Determinants of Certification Decisions among Coffee Farmers}

Level of specialization, membership in organizations, and years of experience in coffee farming activities significantly influenced the decision to engage in the certification scheme under the two outcomes of household income and environmental conservation $(p<0.05)$ (Table 4). We used the level of specialization as the measure of economies of scale [36]. The findings show that an increase in the level of specialization in coffee production activities increased the predicted probability for coffee farmers to become certified. This means that the more specialized the coffee farmers were, the more they were likely to become certified. However, farming households tend to pursue risk diversification objectives which reduce their level of specialization. Therefore, the most important indicator for coffee farmers to have a high chance of joining the certification schemes is economies of scale. Economies of scale indicate how a farmer can be able to intensify in the coffee production system. Farmers exercising a high level of intensification in coffee production may have a high chance of joining the certification scheme. Similarly, the study by Volsi, Telles [37] indicated how specialization is essential for driving intensification in the production system. 
Table 4. Determinants of certification decisions among coffee farmers.

\begin{tabular}{|c|c|c|c|c|}
\hline \multirow{2}{*}{ Variable } & \multicolumn{2}{|c|}{ Household Income } & \multicolumn{2}{|c|}{ Environmental Conservation } \\
\hline & Coeff. & $p>|Z|$ & Coeff. & $p>|Z|$ \\
\hline Education & -0.030 & 0.285 & -0.034 & 0.211 \\
\hline Level of specialization & $0.009 * * *$ & 0.001 & $0.009^{* * *}$ & 0.001 \\
\hline Membership & $0.792^{* * *}$ & 0.000 & $0.536^{* * *}$ & 0.000 \\
\hline Market outlet & 0.273 & 0.405 & $0.527 *$ & 0.098 \\
\hline Sex & 0.212 & 0.323 & 0.247 & 0.244 \\
\hline Experience & $0.015^{* * *}$ & 0.001 & $0.013^{* * *}$ & 0.000 \\
\hline Wealth & $-0.000017^{* * *}$ & 0.002 & $-1.49 \times 10^{6}$ & 0.708 \\
\hline Constant & -3.303 & 0.000 & -2.595 & 0.000 \\
\hline Correlation $(\mathrm{r} 1)$ & 0.077 & 0.860 & -1.756 & 0.000 \\
\hline Correlation $(\mathrm{r} 2)$ & 1.033 & 0.000 & -0.360 & 0.181 \\
\hline$n$ & \multicolumn{2}{|c|}{400} & \multicolumn{2}{|c|}{400} \\
\hline Model statistic & \multicolumn{2}{|c|}{$\begin{array}{l}\text { Wald chi2 }(5)=14.02 \\
\text { prob }>\text { chi } 2=0.029\end{array}$} & \multicolumn{2}{|c|}{$\begin{array}{l}\text { Wald chi2 } 2(5)=28.34 \\
\text { prob }>\text { chi } 2=0.000\end{array}$} \\
\hline
\end{tabular}

${ }_{* * *} p<0.01, * p<0.1$.

Membership in organizations increased the predicted probability of becoming certified. Membership is the measure of participation in collective action. The participation of coffee farmers in collective action is an important method to obtain information on various niche markets that would lead to their involvement in certification schemes. Collective actions are also essential to spur knowledge transfer among the coffee farmers. Therefore, coffee farmers should be encouraged to have membership in various organizations which will support their coffee production and marketing activities, easing the chance of becoming certified. Participation in collective action is vital. Similarly, a study by Bravo-Monroy, Potts [6] in Colombia indicated membership to be a key element in supporting coffee farmers to make decisions on certification.

Years of experience in coffee farming activities increased the chance of farmers making a decision to become certified. An increase in years of coffee farming experience increases the predicted probability of becoming certified. This means that the more experienced coffee farmers have a higher chance of becoming certified than the less experienced coffee farmers. Experience is always accompanied by improved knowledge and skills in farming practices. Experienced farmers have skills in managing coffee and other related activities. This increases the efficiency of their farming activities, leading to them being in a better position for making a decision to become certified.

Surprisingly, the wealth status of the coffee farmers reduced the chance of becoming certified. Findings indicate that an increase in the wealth of the coffee farmer reduces the predicted probability of becoming certified. The wealthier coffee farmers have a lower chance of joining the certification schemes. This is due to the fact that rich farmers have diversified their capital into investing in production of other better-paying crops such as banana, avocado, and other horticultural products.

In pursuing environmental conservation objectives, the market outlet used by the coffee farmers was found to be imperative. Coffee farmers selling through AMCOS were found to have a higher predicted probability of becoming certified than farmers who sold coffee via the other market outlets. Additionally, sex of the plot manager and level of education were not significant determinants of coffee farmers' decision to engage in certification schemes.

\subsection{Coffee Farmers' Awareness and Practice of Environmental Conservation}

The study established the level of awareness and practice of environmental conservation among coffee farmers. Results indicated that $59.5 \%$ of coffee farmers are not aware of the environmental effects associated with coffee production activities. This brings out the need for environmental education to be provided to coffee farmers. Interestingly, the sustainable production practices for coffee that conserve the environment, general biodiversity, 
and ecosystem were known to many coffee farmers (53.6\%), especially the certified coffee farmers $(63.6 \%)$, and they practiced sustainable production. However, some non-certified coffee farmers (39.4\%) indicated that they faced barriers in practicing sustainable coffee production/trade in their area. The barriers included inaccessibility to knowledge and some of the production inputs. Generally, certified coffee farmers face fewer barriers in practicing sustainable coffee production/trade in their area. They are more informed and they practice sustainable coffee production that conserves the environment, biodiversity, and ecosystems in contrast to the non-certified coffee farmers.

Nevertheless, many coffee farmers $(65 \%)$ in both groups $(77.1 \%$ for certified farmers and $59.9 \%$ for non-certified farmers) were found to be using measures that minimize environmental effects associated with coffee production. These measures include use of the mulching method for increasing water porosity, water retention capacity, and stability. This was practiced by $46 \%$ of the coffee farmers, of which many were certified farmers and were statistically significantly different from the non-certified farmers (Table 5) $(p<0.05)$. These methods conserve the environment and protect coffee farms from soil erosion. The other methods used to avoid soil erosion are planting trees, use of contours, construction of water streams, and terracing. However, this method was used by few (28.2\%) farmers. The construction of water streams is used to avoid soil erosion and water loss. Additionally, many coffee farmers (92\%) practice intercropping of coffee with leguminous crops to improve soil health by adding soil nutrients. The intercropping of coffee with trees and other beneficial plants enhances biodiversity in coffee production activities.

Table 5. Environmental conservation practices among coffee farmers.

\begin{tabular}{|c|c|c|c|c|}
\hline \multirow{2}{*}{ Environmental Practice } & \multicolumn{2}{|c|}{ Farmers Practicing (\%) } & \multirow{2}{*}{ Overall } & \multirow{2}{*}{$\chi^{2}$ Statistics } \\
\hline & Certified & Non-Certified & & \\
\hline $\begin{array}{l}\text { Use of mulching method for increasing water } \\
\text { porosity, water retention capacity, and stability }\end{array}$ & 69.2 & 35.5 & 46.0 & $43.975(0.00)+* * *$ \\
\hline $\begin{array}{l}\text { Planting trees, use of contours, construction of } \\
\text { water streams, and terracing }\end{array}$ & 39.3 & 23.2 & 28.2 & $13.391(0.00)^{* * *}$ \\
\hline $\begin{array}{c}\text { Intercropping coffee with trees and other } \\
\text { beneficial plants }\end{array}$ & 94.0 & 91.1 & 92.0 & $6.473(0.011)^{* *}$ \\
\hline Water resources conservation & 6.0 & 10.0 & 8.8 & $1.188(0.276)$ \\
\hline Proper use of agrochemicals & 16.2 & 22.4 & 20.5 & $1.067(0.302)$ \\
\hline
\end{tabular}

+ Values in brackets are $p$-values; ${ }^{* * *} p<0.01, * * p<0.05$.

Water resource conservation is another method that was practiced by a few coffee farmers $(8.8 \%)$ for minimizing environmental effects associated with coffee production and did not vary between the two groups. The practices of water conservation included the construction of a water sewage system, especially during the processing of coffee to reduce environmental pollution. Coffee primary processing requires a lot of water. Coffee farmers indicated performing home processing using their own pulping machines. Water is the most important ingredient in pulping. Some coffee farmers ensure that there is no washing of coffee alongside water sources such as ponds, rivers, springs, and canals. Additionally, coffee farmers ensure they practice farming away from water sources in order to minimize water pollution caused by agrochemicals used in farming, especially during the rainy season.

The proper use of agrochemicals is another area being observed by some coffee farmers (20.5\%) in conserving the environment. This includes the use of recommended application methods, amount, and frequency of using herbicides, pesticides, and insecticides. However, coffee farmers involved in certification schemes, especially organic farming, reported using herbs in pest and disease treatment methods that are environmentally friendly. Other methods for those using agrochemicals included the collection and burning of packaging materials used for agrochemicals that could add poison to the environment and affect biodiversity as well as endanger personal health. 


\subsection{Factors Affecting the Outcome Variables between Certified and Non-Certified Farmers}

Sex of the coffee plot manager, education, market outlet, level of specialization, and membership in organizations were found to significantly affect the outcome variables which are household income and environmental conservation $(p<0.05)$ (Table 6). Sex of the farmer and level of education influenced the total household income generated by the farmer. Male farmers were found to have a greater predicted probability of obtaining higher household incomes than females. This was true for both certified and non-certified coffee farmers. This is due to the fact that women have low access and control over various resources in the study areas which are key contributors to household incomes. Additionally, an increase in the level of education was found to increase the predicted probability of obtaining high household incomes for certified coffee farmers.

Table 6. Factors Affecting the Outcome Variables between Certified and Non-Certified Farmers.

\begin{tabular}{|c|c|c|c|c|c|}
\hline & \multirow[t]{2}{*}{ Variable } & \multicolumn{2}{|c|}{ Household Income } & \multicolumn{2}{|c|}{$\begin{array}{l}\text { Environmental } \\
\text { Conservation }\end{array}$} \\
\hline & & Coeff. & $p>|Z|$ & Coeff. & $p>|Z|$ \\
\hline \multirow{8}{*}{$\begin{array}{l}\text { Certified } \\
\text { farmers }\end{array}$} & Sex & 0.509 * & 0.069 & $-0.446^{*}$ & 0.098 \\
\hline & Education & $0.0916^{* * *}$ & 0.007 & 0.006 & 0.866 \\
\hline & $\begin{array}{c}\text { Level of } \\
\text { specialization }\end{array}$ & 0.0002 & 0.965 & $-0.013^{* * *}$ & 0.000 \\
\hline & Membership & -0.004 & 0.985 & $0.689^{* * *}$ & 0.000 \\
\hline & Market outlet & -0.639 & 0.150 & -0.527 & 0.220 \\
\hline & Constant & 5.697 & 0.000 & 6.895 & 0.000 \\
\hline & Sex & $0.690^{* * *}$ & 0.001 & 0.214 & 0.212 \\
\hline & Education & 0.0357 & 0.142 & 0.025 & 0.219 \\
\hline \multirow[t]{8}{*}{$\begin{array}{l}\text { Non-certified } \\
\text { farmers }\end{array}$} & $\begin{array}{c}\text { Level of } \\
\text { specialization }\end{array}$ & 0.005 & 0.109 & -0.002 & 0.394 \\
\hline & Membership & $0.235 *$ & 0.086 & $0.214^{*}$ & 0.076 \\
\hline & Market outlet & $0.574^{* *}$ & 0.014 & 0.301 & 0.114 \\
\hline & Constant & 5.051 & 0.000 & 2.566 & 0.000 \\
\hline & Correlation (r1) & 0.077 & 0.860 & -1.756 & 0.000 \\
\hline & Correlation (r2) & 1.033 & 0.000 & -0.360 & 0.181 \\
\hline & $n$ & \multicolumn{2}{|c|}{400} & \multicolumn{2}{|c|}{400} \\
\hline & Model statistic & \multicolumn{2}{|c|}{$\begin{array}{c}\text { Wald chi } 2(5)=14.02 \\
\text { prob }>\text { chi } 2=0.029\end{array}$} & \multicolumn{2}{|c|}{$\begin{array}{l}\text { Wald chi } 2(5)=28.34 \\
\text { prob }>\text { chi } 2=0.000\end{array}$} \\
\hline
\end{tabular}

${ }_{* * *} p<0.01,{ }^{* *} p<0.05,{ }^{*} p<0.1 ; \mathrm{r} 1$ and $\mathrm{r} 2$ are first and second correlations respectively.

The level of specialization and sex of the farmer were found to significantly reduce the predicted probability of being aware of and practicing environmental conservation for certified coffee farmers. Male coffee farmers were found to be less concerned with environmental conservation than female. Likewise, the more specialized coffee farmers were found to be less concerned with environmental conservation practices. However, membership in organizations increased the chance of being aware and practicing environmental conservation for both certified and non-certified coffee farmers. Additionally, membership in various organizations and use of AMCOS as the market outlet increased the predicted probability of obtaining high household incomes for the non-certified coffee farmers.

\subsection{The Effect of Certification Decisions on Environmental Conservation and Livelihood Improvement}

Coffee farmers who were not in the certification schemes earned higher coffee and total household incomes than certified coffee farmers. The $t$-test results indicated significant differences in annual incomes earned between the two coffee farmer groups $(p<0.05)$. Income earned from coffee production activities by certified coffee farmers was USD 490.91 lower than that of non-certified coffee farmers. Similarly, non-certified coffee farmers had a mean annual household income that was USD 762.06 higher than that earned by their counterpart certified farmers (Table 7). This implies that there are challenges confronting 
certified farmers that cause them to fail to gain the anticipated benefits, including increased incomes. The differences are reported to emanate from coffee productivity, farm sizes, and the fact that the price premiums are not paid to certified coffee farmers.

Table 7. Annual income differences between certified and non-certified farmers.

\begin{tabular}{cccc}
\hline $\begin{array}{c}\text { Coffee Farmer } \\
\text { Group }\end{array}$ & $\begin{array}{c}\text { Mean Annual Coffee } \\
\text { Income (USD) }\end{array}$ & $\begin{array}{c}\text { Mean Annual Total } \\
\text { Household Income (USD) }\end{array}$ & $n=\mathbf{4 0 0}$ \\
\hline Certified & 730.12 & 1587.55 & 118 \\
Non-certified & 1221.03 & 2349.61 & 282 \\
Difference & 490.12 & 762.06 & \\
T test statistics & $t=1.7056 ; \mathrm{df}=398 ;$ & $t=1.7293 ; \mathrm{df}=398 ;$ \\
& Pr. $(\mathrm{T}>\mathrm{t})=0.044^{* *}$ & $\operatorname{Pr}(\mathrm{T}>\mathrm{t})=0.0423^{* *}$ & \\
\hline
\end{tabular}

United States Dollars (USD) $=2305.10$ Tanzanian Shillings (TZS), the average exchange rate for the year 2020 [17] ** $p<0.05$ for $t$ test of differences in mean incomes; $n$ is the number of farmers/observations; $\mathrm{df}=$ degrees of freedom and $\operatorname{Pr}$ is the probability.

Further analysis on the average treatment effects on the treated (ATT) and the average treatment effects on the untreated (ATU) showed a negative value of ATT for the total household income outcome variable and a positive on the environmental conservation. This suggests that coffee farmers who are not in the certification schemes earned higher household incomes than certified farmers. This means that the findings reject the hypothesis of certification to improve household income, on the one hand. On the other hand, certification improves awareness and practice of environmental conservation among coffee farmers (Table 8). Certified coffee farmers are better placed in conserving the environment. These findings are in line with Kattel [38], who found certification, especially group organic certification, enhances environmental sustainability. Therefore, certification leads to improved environmental conservation. This is due to the fact that certification schemes are always accompanied by environmental conservation indicators such as pesticide use, water and energy conservation, and biodiversity. Therefore, smallholder coffee certification contributes more to environmental conservation and other sustainability indicators than increased incomes, especially for developing countries like Tanzania.

Table 8. Average treatment effects for certified and non-certified coffee farmers.

\begin{tabular}{ccccc}
\hline \multirow{2}{*}{ Variable } & \multicolumn{2}{c}{ Household Income $\ddagger$} & \multicolumn{2}{c}{ Environmental Conservation } \\
\cline { 2 - 5 } & \multicolumn{1}{c}{ ATT } & ATU & ATT & ATU \\
\hline Mean & $-2.783^{* * *}$ & $2.449^{* * *}$ & 2.801 & $1.418^{* * *}$ \\
Statistic & $-8.85(0.00)+$ & $6.788(0.00)$ & $14.102(1.00)$ & $11.169(0.00)$ \\
\hline
\end{tabular}

$\mp$ Values in brackets are p-values based on ttest; $\ddagger$ the log of total household income in USD was used in the analysis; ${ }^{* * *} p<0.01$; ATT is the average treatment effect on the treated/certified farmers and ATU is the average treatment effect on the untreated/non-certified farmers.

\subsection{Key Challenges in Coffee Certifications}

The study identified challenges in accessing certification schemes for some of the coffee farmers. Farmers indicated that they experienced compliance issues with some of the certification schemes. The terms and conditions spelt out in joining the schemes were difficult to comply with. The level of awareness on the availability of different niche markets and opportunities from certification schemes was not known with certainty by many coffee farmers in the study areas. This can be linked to the inefficiencies in sharing market information within the coffee supply chain.

Many coffee farmers (49.8\%) disagreed on whether it was easy to access niche export coffee markets. Few coffee farmers $(23.3 \%)$ were indifferent and the remaining proportion $(26.9 \%)$ indicated that they agreed with the statement. The level of agreement on the statements is shown in Figure 5. The Likert scale responses were such that $1(20 \%)$ was strongly disagree, $2(40 \%)$ was disagree, $3(60 \%)$ was neutral/indifferent, $4(80 \%)$ was 
agree, and $5(100 \%)$ was strongly agree. Coffee farmers who agreed on a statement are above the neutral/indifferent line $(60 \%)$ which separates level of agreement and that of disagreement, while coffee farmers who disagreed on a stated statement are indicated below the neutral line $(60 \%)$. Many of the coffee farmers who disagreed on easiness in accessing the niche markets were in the non-certified group. Non-certified coffee farmers experienced difficulties in accessing the certification services. They lacked information on the availability of certification services and also experienced issues related to compliance. However, even if the certification services were accessible, many coffee farmers (56.6\%) from both groups disagreed with the statement of them being easy to obtain.

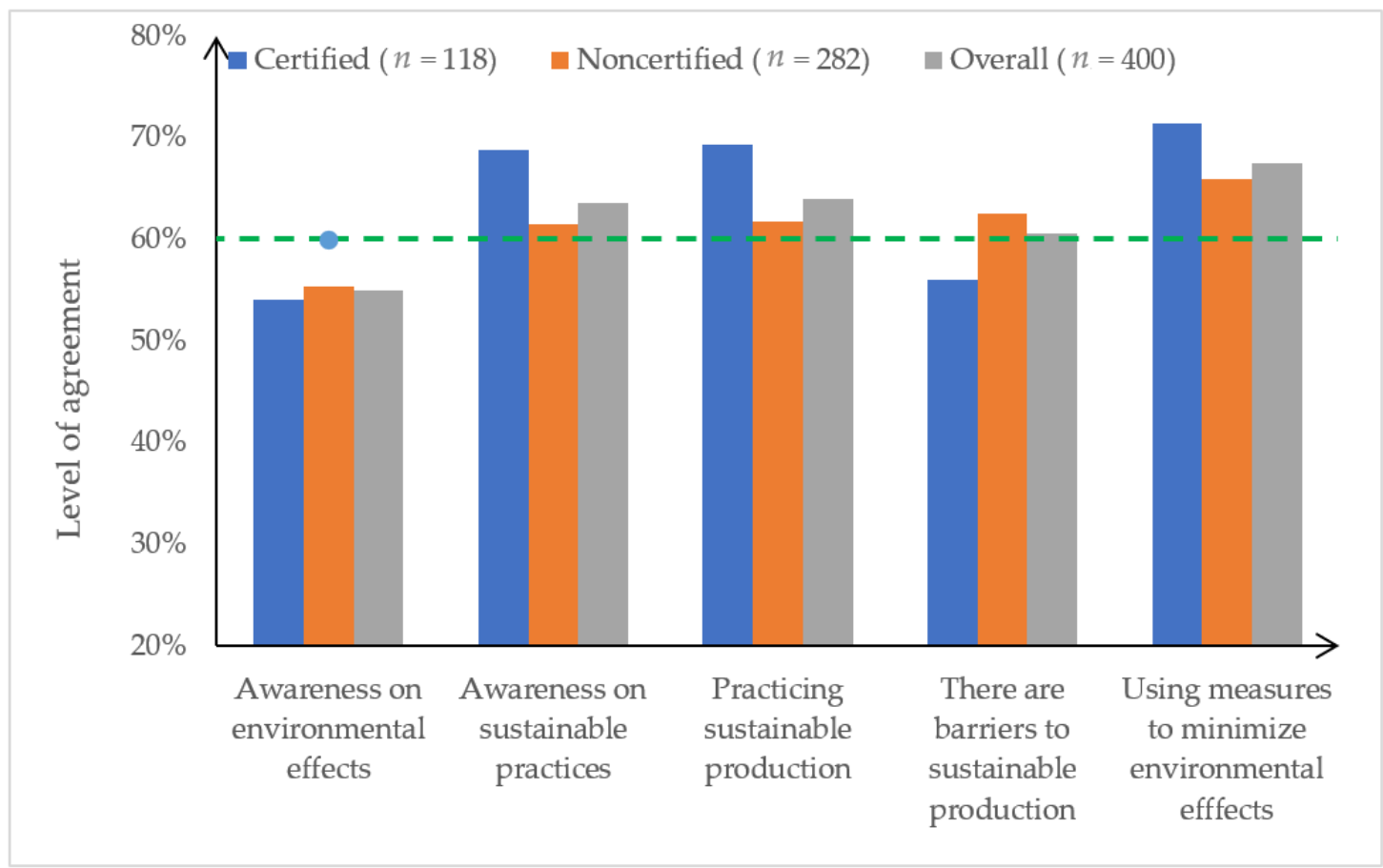

Figure 5. Level of agreement on various certification statements. Source: Coffee farmers' household survey, 2021 data.

The prevalence of coffee diseases, such as coffee berry disease (CBD) (Colletotrichum kahawae), was mentioned as one of the reasons that made some coffee farmers hesitate to obtain organic coffee farming certification. CBD has been affecting coffee farmers for quite a long time. Similarly, the study by Otieno, Alwenge [39] identified CBD as being one of the key diseases affecting coffee farmers in Tanzania. Some coffee farmers reported non-availability of organic agricultural inputs to support them once they are certified. They indicated that these inputs were readily available in their location, but their commercialization and availability in bulk was a major constraining factor. This affected the ability of farmers in the study areas to comply with organic certification. In fact, some coffee farmers could not realize the price advantage and yield gains expected from joining the certification schemes. The findings of our study indicate that some farmers sold their organic coffee at relatively similar prices as those offered by farmers who were not certified, hence failing to benefit from price premiums. Generally, certified coffee farmers sold their coffee at $1.1 \mathrm{USD} / \mathrm{Kg}$ of parchment while the non-certified farmers sold at $1.4 \mathrm{USD} / \mathrm{Kg}$. The difference is attributed to the associated transaction costs in both groups and buyers' differences. Transmission of price premiums to coffee farmers is a challenge in many countries. The study by Rich, PG [40] in India found the premiums to be small. Similarly, the study by Minten, Dereje [21] in Ethiopia also found the premiums to be hardly transmitted to farmers. This indicates that the price advantages are captured by other actors along the coffee supply chain. The key informants' results from our study revealed the existence of quality-related issues and overregulation of the coffee marketing system, 
which in turn hindered coffee farmers from benefiting from price advantages. However, many coffee farmers $(60.6 \%)$ reported that their coffee met international standards in terms of quality. More certified coffee farmers indicated that they had better quality coffee than the non-certified coffee farmers.

The state of government regulation in the sector was mentioned by many coffee farmers as challenging. Our results show that $54.8 \%$ of the coffee farmers agreed with the assertion that the existing government regulations and restrictions constitute the major obstacle to coffee trade. The level of agreement was higher for non-certified coffee farmers than the certified coffee farmers. Farmers indicated complications associated with direct coffee exports. The involvement of private buyers in buying coffee directly from farmers has also been limited by the new government regulations that require all coffee to go through the auction system.

The other challenge identified was coffee productivity. Some farmers $(25.5 \%)$ indicated that they faced productivity challenges regardless of the certification scheme. Organic certified farmers reported obtaining lower productivity by $34.7 \mathrm{~kg} / \mathrm{ha}$ compared to their counterparts. This is because the organic fertilizers, pesticides, and herbicides are cumbersome to obtain. The low productivity leads to increased production costs affecting the whole coffee production efficiency. The price premiums that are expected to offset the productivity gap are hard to obtain.

Additionally, $56.8 \%$ of the coffee farmers surveyed indicated that certification was not cost effective. The costs vary, ranging from 150-500 USD/ha and an annual auditing fee of USD 1000-5000. The high cost of certification and auditing makes coffee farmers lose their sovereignty in accessing the price premiums. This is because the certification and auditing costs are thus paid by traders or exporting companies, for which reciprocating the benefits to the coffee farmers seems not to be working for the coffee farmers. However, certification is increasingly viewed as necessary to be able to access export coffee markets.

\section{Conclusions}

Certification is increasingly perceived as necessary for accessing export markets among coffee farmers in developing countries. Coffee farmers need to join the certification schemes to be capable of accessing niche export markets and to gain social, economic, and environmental benefits associated with certification. Certification-enhancing policies will spur the production of sustainably grown coffee, social equity, and overall sustainability within the coffee supply chain.

This study faced two main limitations which were dealt with during data collection, cleaning, and analysis. These limitations were respondents' recall bias and the use of gross income rather than net income to measure livelihood improvement. Many of the respondents do not keep records or inventories of costs, purchases, and revenues. This affects the reporting of the revenues and cost streams. However, the study has well highlighted the status, constraints, key drivers, and impact of the coffee certifications in Tanzania as one of the coffee producers in developing countries. The level of coffee certification is still low, requiring interventions that will address the key constraints of certification. The key constraints include the low level of awareness and accessibility, the prevalence of coffee diseases, failure in realizing price advantage, and certification not being cost-effective for coffee farmers. The study also found that the decision of the coffee farmer to join a certification scheme was influenced by factors including economies of scale, experience, and participation in collective actions. Additionally, the study rejects the hypothesis of certification to improve household incomes. Nevertheless, certification improved awareness and practice of environmental conservation among coffee farmers.

It is thus important for private and public institutions to embark on awareness creation and make certification services accessible and cost effective to coffee farmers as well as enhancing access to niche export markets. Easing transmission of price premiums to coffee farmers will increase the supply of sustainably grown coffee, improve coffee farmers livelihoods, and attain environmental sustainability goals within the coffee supply chain. 
Author Contributions: Conceptualization, J.R.K.; methodology, J.R.K. and C.P.M.; software, J.R.K.; validation, B.P.M., J.K. and P.K.T.M.; formal analysis, J.R.K.; investigation, B.P.M., R.M.J.K. and J.R.K.; resources, R.M.J.K.; data curation, J.R.K.; writing - original draft preparation, J.R.K.; writingreview and editing, R.M.J.K.; visualization, J.R.K.; supervision, R.M.J.K.; project administration, R.M.J.K.; funding acquisition, R.M.J.K. All authors have read and agreed to the published version of the manuscript.

Funding: This research was funded by the UK Research and Innovation's Global Challenges Research Fund (UKRI GCRF) through the Trade, Development and the Environment Hub Project (Project number ES/S008160/1).

Institutional Review Board Statement: The study was conducted according to the UN Environment Programme World Conservation Monitoring Centre (UNEP-WCMC) Code of Practice on Ethical Standards in Research, and approved by the Trade, Development and the Environment Hub (TRADE Hub) Research Ethics Committee on 12th October 2020.

Informed Consent Statement: Informed consent was obtained from all subjects involved in the study.

Data Availability Statement: The data presented in this study are available on request from the authors.

Acknowledgments: The authors gratefully acknowledge Elizabeth J Z Robinson of the University of Reading, the UK, for her guidance during the development of this article. All the coffee farmers from Kagera, Kilimanjaro, Mbeya, Ruvuma, and Songwe regions of Tanzania are acknowledged for their participation in the study and for their willingness to provide information.

Conflicts of Interest: The authors declare no conflict of interest.

\section{References}

1. Jena, P.R.; Stellmacher, T.; Grote, U. Can coffee certification schemes increase incomes of smallholder farmers? Evidence from Jinotega, Nicaragua. Environ. Dev. Sustain. 2017, 19, 45-66. [CrossRef]

2. Bellmann, C.; Hepburn, J. The decline of commodity prices and global agricultural trade negotiations: A game changer? Int. Dev. Policy 2017. [CrossRef]

3. CBI. Exporting Sustainable Coffee to Europe. Available online: https://www.cbi.eu/market-information/coffee/sustainablecoffee (accessed on 25 March 2021).

4. Makita, R.; Tsuruta, T. Fair Trade and Organic Initiatives in Asian Agriculture: The Aidden Realities: Routledge Studies in Development Economics; Routledge Studies in Development Economics; Taylor \& Francis: New York, NY, USA, 2017; p. 160.

5. FAO. The Broad Range of Certification Schemes. Available online: http://www.fao.org/3/ai388e/AI388E09.htm (accessed on 5 April 2021).

6. Bravo-Monroy, L.; Potts, S.G.; Tzanopoulos, J. Drivers influencing farmer decisions for adopting organic or conventional coffee management practices. Food Policy 2016, 58, 49-61. [CrossRef]

7. Pyk, F.; Abu Hatab, A. Fairtrade and sustainability: Motivations for fairtrade certification among smallholder coffee growers in Tanzania. Sustainability 2018, 10, 1551. [CrossRef]

8. Lentijo, G.M.; Hostetler, M. Evaluating Certified Coffee Programs; The Institute of Food and Agricultural Sciences, University of Florida: Gainesville, FL, USA, 2011; p. 6.

9. Rosen, M.A.; Kishawy, H.A. Sustainable manufacturing and design: Concepts, practices and needs. Sustainability 2012, 4, 154-174. [CrossRef]

10. Voora, V.; Bermúdez, S.; Larrea, C. Global Market Report: Coffee. In Sustainable Commodities Marketplace Series 2019; The International Institute for Sustainable Development: Winnipeg, MB, Canada, 2019; p. 6.

11. Mhando, D.G.; Mdoe, N. Why Do Smallholder Famers in Four Tanzanian Districts Continue with Coffee Production Despite Fluctuating Prices? J. Agric. Life Sci. Vol. 2018, 5, 14-23. [CrossRef]

12. TCB. Tanzania Coffee Industry Profile. Available online: https://www.coffeeboard.or.tz/tzcoffee_\%20profile.php (accessed on 26 March 2021).

13. ICO. Coffee Production Report. Available online: http://www.ico.org/prices/pr-prices.pdf (accessed on 26 March 2021).

14. FAO. Production Quantity Data. Available online: http://www.fao.org/faostat/en/\#data/QC (accessed on 26 March 2021).

15. Marwa, N. Unlocking Coffee Production in Tanzania: What Does the Future Holds? Policy Brief No.7 of 2019. Available online: https:/ / www.tadb.co.tz/wp-content/uploads/2020/07/Policy-Brief_7_2019_Coffee.docx.pdf (accessed on 25 March 2021).

16. ITC. Trade Statistics for International Business Development-TRADE MAP. Available online: https://www.trademap.org/ (accessed on 26 March 2021).

17. BOT. Bank of Tanzania Annual Report; Bank of Tanzania: Dar es Salaam, Tanzania, 2020; p. 247.

18. Meier, C.; Sampson, G.; Larrea, C.; Schlatter, B.; Voora, V.; Dang, D.; Bermudez, S.; Wozniak, J.; Willer, H. The State of Sustainable Markets 2020: Statistics and Emerging Trends; International Trade Centre (ITC): Geneva, Switzerland, 2020; p. 84. 
19. Junior, R.M.; Franks, D.M.; Ali, S.H. Sustainability certification schemes: Evaluating their effectiveness and adaptability. Corp. Gov. 2016, 16, 579-592. [CrossRef]

20. Van Rijsbergen, B.; Elbers, W.; Ruben, R.; Njuguna, S.N. The ambivalent impact of coffee certification on farmers' welfare: A matched panel approach for cooperatives in Central Kenya. World Dev. 2016, 77, 277-292. [CrossRef]

21. Minten, B.; Dereje, M.; Engida, E.; Tamru, S. Tracking the quality premium of certified coffee: Evidence from Ethiopia. World Dev. 2018, 101, 119-132. [CrossRef]

22. Schleifer, P.; Sun, Y. Reviewing the impact of sustainability certification on food security in developing countries. Glob. Food Secur. 2020, 24, 100337. [CrossRef]

23. NBS. 2016/17 Annual Agricultural Sample Survey Report; National Bureau of Statistics (NBS): Dar es Salaam, Tanzania, $2017 ;$ p. 99.

24. Nicholson, W.; Snyder, C. Microeconomic Theory: Basic Principles and Extensions, 10th ed.; Thomson South-Western: Natorp Boulevard, OH, USA, 2008; p. 763.

25. Cascetta, E. Random utility theory. In Transportation Systems Analysis: Models and Applications; Cascetta, E., Ed.; Springer: Boston, MA, USA, 2009; pp. 89-167. [CrossRef]

26. Dorman, P. Microeconomics; Springer Texts in Business and Economics; Springer: Berlin/Heidelberg, Germany, $2014 ;$ p. 528. [CrossRef]

27. Debertin, D.L. Agricultural Production Economics; Macmillan Publishing Company: Upper Saddle River, NJ, USA, $2012 ;$ p. 432.

28. Weersink, A.; Fulton, M. Limits to profit maximization as a guide to behavior change. Appl. Econ. Perspect. Policy 2020, 42, 67-79. [CrossRef]

29. Yamane, T. Statistics: An Introductory Analysis, 2nd ed.; Harper \& Row: New York, NY, USA, 1967; p. 919.

30. Ssebunya, B.R.; Schader, C.; Baumgart, L.; Landert, J.; Altenbuchner, C.; Schmid, E.; Stolze, M. Sustainability performance of certified and non-certified smallholder coffee farms in Uganda. Ecol. Econ. 2019, 156, 35-47. [CrossRef]

31. Greene, W.H. Econometrics Analysis, 8th ed.; Pearson Education, Inc., Publishing Prentice Hall: Upper Saddle River, NJ, USA, 2018; p. 1168.

32. Lokshin, M.; Sajaia, Z. Maximum likelihood estimation of endogenous switching regression models. Stata J. 2004, 4, 282-289. [CrossRef]

33. Barham, J.; Chitemi, C. Collective action initiatives to improve marketing performance: Lessons from farmer groups in Tanzania. Food Policy 2009, 34, 53-59. [CrossRef]

34. Ochieng, J.; Knerr, B.; Owuor, G.; Ouma, E. Strengthening collective action to improve marketing performance: Evidence from farmer groups in Central Africa. J. Agric. Educ. Ext. 2018, 24, 169-189. [CrossRef]

35. Twine, E.E.; Rao, E.J.O.; Baltenweck, I.; Omore, A.O. Are technology adoption and collective action important in accessing credit? Evidence from milk producers in Tanzania. Eur. J. Dev. Res. 2019, 31, 388-412. [CrossRef]

36. Assa, M.; Edriss, A.-K.; Matchaya, G. Cost efficiency, Morishima, Allen-Uzawa and cross-price elasticities among Irish potato farmers in Dedza District, Malawi. Int. J. Econ. Sci. Appl. Res. 2013, 6, 59-73.

37. Volsi, B.; Telles, T.S.; Caldarelli, C.E.; Camara, M.R.G.D. The dynamics of coffee production in Brazil. PLoS ONE 2019, 14, e0219742. [CrossRef]

38. Kattel, R. Impacts of group organic certification of coffee on socio-economic and environmental sustainability in Nepal. J. Agric. For. Univ. 2017, 1, 49-60.

39. Otieno, H.M.; Alwenge, B.A.; Okumu, O.O. Coffee Production Challenges and Opportunities in Tanzania: The Case Study of Coffee Farmers in Iwindi, Msia and Lwati Villages in Mbeya Region. Asian J. Agric. Hortic. Res. 2019, 3, 1-14. [CrossRef]

40. Rich, K.M.; PG, C.; Muniyappa, A.; Yadava, C.G.; Manjyapura, G.S.; Pradeepa Babu, B.N.; Shubha, Y.C.; Rich, M. Coffee certification in India: Awareness, practices, and sustainability perception of growers. Agroecol. Sustain. Food Syst. 2018, 42, 448-474. [CrossRef] 